\title{
A SOBERANA VIRTUDE DA CLEMÊNCIA PROCLAMADA PELO TRIBUNAL DO JÚRI E SEUS CONTORNOS JURISPRUDENCIAIS
}

\author{
THE SOVEREIGN VIRTUE OF CLEMENCE PROCLAIMED BY THE COURT OF JURY AND ITS \\ JURISPRUDENTIAL CONTOURS
}

\author{
Edson Damas Silveira ${ }^{22}$ \\ Luiz Fernando Castanheira Mallet ${ }^{23}$
}

Artigo recebido em: 20/11/2018.

Artigo aprovado em: 17/12/2018.

\begin{abstract}
Resumo: o presente artigo objetiva lançar luzes sobre limites à soberana decisão do Tribunal do Júri, a partir da possibilidade de se absolver por clemência o acusado, ainda que reconhecida materialidade do delito e sua autoria devidamente provada dentro do processo. Diante dessa realidade, pode o Órgão de Acusação manejar apelação alegando decisão manifestadamente contrária às provas dos autos e, bem por isso, provocar o Tribunal Recursal a fim de rever o veredicto proferido em primeiro grau, nos exatos termos permitidos pela legislação processual vigente. Como metodologia adotou-se a revisão bibliográfica sobre o tema. Como metodologia o artigo adota a revisão bibliográfica sobre o tema.
\end{abstract}

Palavras-chave: tribunal do júri; soberania; clemência.

Abstract: this article aims to shed light on the sovereign decision of the jury, based on the possibility of acquittal by clemency of the accused, although the materiality of the crime and its authorship duly proven are acknowledged in the process. Faced with this reality, the Appellate Body can handle an appeal alleging that the decision is manifestly contrary to the evidence in the case and, therefore, provoke the Appeal Court to review the verdict handed down in the first degree, in the exact terms allowed by the current procedural law. As a methodology, the article adopts the bibliographic review on the subject.

Keywords: jury court; sovereignty; clemency.

\section{INTRODUÇÃO}

O presente artigo objetiva lançar luzes sobre limites à soberana decisão do Tribunal do Júri, a partir da possibilidade de se absolver por clemência o acusado, ainda que reconhecida materialidade do delito e sua autoria devidamente provada dentro do processo. Diante dessa realidade, pode o Órgão de Acusação manejar apelação alegando decisão manifestadamente contrária às provas dos autos e, bem por isso, provocar o Tribunal Recursal a fim de rever o veredicto proferido em primeiro grau, nos exatos termos

\footnotetext{
${ }^{22}$ Procurador de Justiça em Roraima, especialista, mestre e doutor em direito, professor da Especialização em Direito Socioambiental da PUC/Pr. e do Mestrado em Direito Ambiental da UEA.

23 Procurador de Justiça em Roraima, especialista, mestre e doutor em direito, professor da Especialização em Direito Socioambiental da PUC/Pr. e do Mestrado em Direito Ambiental da UEA.
} 
permitidos pela legislação processual vigente e como será visto com mais vagar nos desdobramentos deste ensaio.

Essa tormentosa questão de matriz constitucional tem desafiado a inteligência e esforço interpretativo de vários setores funcionais do direito mais recentemente, desde as hostes acadêmicas até o universo forense, com muitos posicionamentos divergentes e formas de se encaminhar a discussão por vezes equivocada.

Em razão do tempo e escassez das linhas neste contexto escrito, e com o escopo de muito mais provocar do que apontar soluções, é que o presente trabalho limita-se a expor as primeiras controvérsias havidas dentro do Superior Tribunal de Justiça (STJ) acerca da matéria, porquanto foro competente para a final exegese da legislação federal aplicável à espécie, sem desconhecer e como antes infirmado que o mesmo assunto também encerra contornos constitucionais, e que oportunamente ainda desaguará no Supremo Tribunal Federal (STF).

Mas para se falar em clemência e discutir suas consequências dentro do secular mecanismo democrático do Júri, primeiramente será necessário desbravar alguma significância histórica construída no ocidente a respeito dela para, em tempos modernos, compreender sua importância enquanto virtude humana, em estreita sintonia com o movimento de conquista dos direitos humanos.

Assim, e sabedores da insuficiência dessa argumentação metafísica para efeitos concretos do direito, explorar-se-á os encaminhamentos determinados pela processualística penal, centrando esforços para compreender clemência também adaptada às necessidades formais da dogmática jurídica. É por essa linha teórica iniciar-se-á a ordem de abordagem, descambando os demais itens para o tecnicismo do direito e focando-se nos pronunciamentos a respeito dela dentro do Superior Tribunal de Justiça.

\section{CLEMÊNCIA ENQUANTO ELEVADA VIRTUDE HUMANA}

Do latim clementia, a idéia corrente e comum reporta ao perdão, indulgência, e benevolência (FERREIRA, 2014), muito parecida com o modo como se trata uma pessoa sujeita a determinada penalidade, consistente em isentar inteiramente o culpado da pena ou moderar sua condenação (SILVA, 1975).

Esse ato de bondade restou apropriado ainda pelo o universo jurídico com um sentido mais estendido, muitas vezes aplicado para indicar a liberalidade das leis ou a moderação da ação governamental, tendente a adotar atos de brandura na solução das questões de ordem coletiva (SILVA, 1975). É nessa quadra de compreensão que se destaca a obra de Sêneca, talvez autor do primeiro e mais contunde tratado 
sobre clemência que tem-se notícia no ocidente, ainda tendo por mérito classificar ela no campo das virtudes morais humanas ${ }^{24}$.

Lúcio Aneu Sêneca nasceu em Córdoba, cidade da Província Romana da Bética, no século um antes de Cristo. Levado criança para Roma, se transformou num dos maiores oradores do seu tempo, forte nos ensinamentos pitagóricos, cínicos e estóicos, com uma rápida passagem por Alexandria, então centro efervescente da vida cultural e religiosa da época (OLIVEIRA, 1998).

No ano 31 d.c. e quando retornou para Roma, Sêneca exerceu vários cargos públicos, quando depois de perseguido nos impérios de Calígula e Cláudio, acabou exilado por oito anos na Ilha da Córsega. Recuperado de lá por Agripina no ano de 49 d.c., volta para Roma a fim de ser o preceptor do seu filho Nero. Com Cláudio assassinado em 54 d.c., Nero ascende ao poder e Sêneca se transforma no seu conselheiro pessoal, sendo nomeado também para o Consilium Principis (CROOK, 1955).

Com ascendência sobre Nero, Sêneca muito aconselhou aquele Soberano para que não se tornasse um tirano e assim permanecesse afastado do Senado. Nessa empreitada, produziu no ano de 56 d.c. a obra De Clementia, descrevendo como ele gostaria que fosse o governo de Nero, tentando dessa maneira tornar o jovem Imperador um sábio estóico. Refletirá naqueles escritos sobre a clemência imperial, procurando transformar Nero numa espécie de espelho da razão universal, num modelo de virtude que traria paz e alegria para todos os súditos. Enfim, concebeu uma obra de persuasão e de propaganda, para que o novo Imperador pudesse usar a seu favor (OLIVEIRA, 1998).

Para o filósofo, clemência enquanto virtude somente acontece quando posta em prática por um ser superior e quando a benevolência for dirigida a seres inferiores. Ao ser clemente, o Imperador se torna útil ao bem público, se guiando pela natureza e se conformando nos trilhos encaminhados pelo logos, uma vez que superior aos homens, só conseguindo manter-se nesse patamar pela prática da clemência (SÊNECA, 1990).

Ele compreende o exercício da clemência sob três aspectos, a saber: - primeiro, como virtude que existe para corrigir os erros humanos; depois como virtude que requer equilíbrio na sua aplicação (não sendo oportuno ter uma clemência promíscua ou banal) e; por fim, como temperança de espírito de quem tem o poder de castigar ou, ainda, a brandura de um superior perante um inferior ao estabelecer a penalidade (SÊNECA, 1990).

Em assim sendo, para Séneca a clemência tem livre arbítrio, porquanto quando se julga segundo ela, não se deve seguir uma fórmula legal, mas pautar-se apenas pela equidade e sentimento de bem comum. Isso quer dizer que aquele que escolhe aplicar a clemência, não o faz por imposições externas (como ditado por regras previamente estabelecidas), mas por mera vontade de fazê-lo no presente momento e ponto final.

\footnotetext{
${ }^{24}$ Sem aprofundamento nesse interessante e relevante tema, entende-se como virtude moral aquela disposição adquirida ou inata habitual de praticar o bem (DUROZOI \& ROUSSEL, 1996).
} 
Como elege o Imperador como árbitro, pois julga a vida e determina a morte das pessoas, será justamente no exercício dessa função que irá precisar da clemência, externando o verdadeiro espírito dos Deuses e não se pautando unicamente por rigores da lei produzida pelos homens (Sêneca, 1990).

Muito claro nos ensinamentos de Sêneca que, enquanto virtude humana legada pela divindade, clemência não se enquadra nos termos do corrente tecnicismo jurídico, fixado a partir de uma racionalidade formal, normativa e previamente concebida. Ela não cabe nos estreitos parâmetros preconizados pelo direito, cuja significação em muito transcende aquele modo humano de regular conduta humana. É algo que supera os parâmetros metodológico daquela área do conhecimento para ser manejado por aqueles de apurado espírito fraternal, seres superiores e capazes de exercitar a mais elevada virtude do perdão.

Isso posto e nos termos relembrados, o maior legado deixado por Sêneca a fim de se pensar sobre a clemência nos dias atuais, diz respeito justamente ao seu completo afastamento do rigor metodológico do direito, não se conformando na mera subsunção dos fatos à abstração fincada anteriormente pela norma, transcendendo seu significado generalizante para se instalar na suprema dimensão da benevolência.

Acredita-se ser esse o motivo pelo qual clemência não consta expressa no rol das excludentes autorizadas pelos Códigos Repressivos, uma vez que opera para além deles e numa superior dimensão de supralegalidade, estando classificada no bojo das mais altas instâncias da virtude humana, coisa que talvez os técnicos da legalidade não consigam de fato visualizar e nem alcançar, até porque comprometidos unicamente com a formal aplicação da lei.

No pensamento de Sêneca, o Imperador enfeixava essa virtude transcendental da clemência porque representava a vontade dos Deuses nessa instância terrena, competindo a ele por isso mesmo a divina missão de julgar pessoas segundo o sagrado sentimento de justiça (SÊNECA, 1990). Como hoje o divino muitas vezes é apartado do profano no direito, vislumbra-se apenas nos legítimos representantes do povo fazer valer essa possibilidade altruísta de perdão, desconsiderando as ordens formais do direito e se soerguendo superiores aos juízos técnicos.

Mais adiante tais fundamentos serão retomados, ao se enfrentar a possibilidade da clemência dentro das hostes processuais do ordenamento jurídico, não deixando de considerar recentes posicionamentos do Superior Tribunal de Justiça - STJ, quando delineou a extensão da soberania dos veredictos proferidos pelo Tribunal Popular do Júri nos casos de crimes tentados ou consumados contra a vida, como se verá a seguir.

\section{SIGILO DAS VOTAÇÕES E SOBERANIA DO TRIBUNAL POPULAR DO JÚRI}

Tendo em mente que o presente texto pode ser lido por neófitos e até leigos no direito, o trabalho inicia-se explicando que o Tribunal do Júri é Órgão Colegiado criado dentro da estrutura do Poder Judiciário, composto por um Presidente Técnico (Juiz Togado e de Carreira) e outros 21 (vinte e um) 
Jurados Leigos, escolhidos entre representantes do povo e dos quais restarão 07 (sete) deles sorteados para cada seção, formando o Conselho de Sentença dentro do respectivo processo.

Nessa quadra de organização, compete ao Magistrado de Carreira presidir cada uma dessas seções, procurando resolver tecnicamente questões de direito e conduzir os trabalhos até final julgamento pelo Conselho de Sentença, ocorrido em sala especial e quando os jurados proferem seus veredictos. Esses mesmos Juízes Leigos decidem por meio de questionário proposto pelo Juiz Presidente, após anuência das partes e cujas decisões são sempre tomadas por maioria.

Feitos esses primeiros esclarecimentos, restringindo-se ao âmbito do direito brasileiro e não desconhecendo que se trata de uma Instituição secular e plurinacional ${ }^{25}$, o Tribunal do Júri remonta ao ano de 1822, quando o Príncipe Regente Pedro I assina o Decreto 0-031, em 18 de junho daquele ano, criando órgão de "Juízes de Fato para julgamento dos crimes de abuso de liberdade de imprensa".

$\mathrm{Na}$ Constituição Imperial de 1824 houve tanto a ratificação daquele decreto como ainda alargamento da mesma Instituição para conhecer e julgar também matérias cíveis, "nos casos e pelo modo que os códigos determinarem" (art. 151). Mas foi somente com a Constituição Republicana de 1891 que o Tribunal de Júri passou a constar topograficamente dentro de capítulos e seções que versavam sobre direitos humanos fundamentais, sendo pioneira na elevação da Corte Popular como uma garantia individual contra o arbítrio do Estado (art. 72, par. 31).

No entanto, fulgurantes retrocessos foram percebidos na Constituição de 1934, quando o Júri voltou para fora do capítulo das declarações e garantias individuais; e bem mais preocupante foi o completo silêncio a respeito dele na Carta de 1937 (TUCCI, 1999). Mas a Instituição ressurge com mais força logo depois, na edição da Constituição Democrática de 1946, quando acabou por prestigiar aquele Tribunal de Leigos novamente como um mecanismo para promoção dos direitos e garantias individuais, tendo-lhe reconhecido a soberania dos seus veredictos (art. 141, par. 28).

A Constituição Militar de 1967, reafirmada pela Emenda n. 01 de 1969, não alterou o anterior texto constitucional nesta parte, herdando de 1946 um Júri soberano e competente para julgamento dos crimes dolosos contra a vida (art. 153, pr. 18). E assim permaneceu na Constituição Cidadã de 1988, devidamente acomodado no título "Dos Direito e Garantias Fundamentais", tendo sido assegurada a plenitude de defesa; sigilo das votações; soberania dos veredictos; e a competência para o julgamento dos crimes dolosos contra a vida (art. $5^{\circ}$, inciso XXXVIII).

Essa deliberada topografia constitucional aloja o Tribunal do Júri em tempos presentes como mais uma garantia individual, protegida por cláusula pétrea e reforçada por outros direitos processuais que dela

\footnotetext{
${ }^{25}$ Para melhor conhecer as origens históricas dessa importante e democrática Instituição do direito, sugere-se consultar o artigo intitulado "O tribunal do júri nos Estados Unidos - sua evolução histórica e algumas reflexões sobre seu estado atual”, tendo como autores Araújo \& Almeida e publicado na Revista Brasileira de Ciências Criminais n. 15, devidamente referenciada ao final deste texto.
} 
decorrem $^{26}$, razão pela qual toda e qualquer interpretação que se construa sobre essa milenar Instituição deve privilegiar o ser humano contra o arbítrio do Estado, ainda que contrária ao sentimento comum coletivo. Não se pode olvidar que justamente por ser contra majoritário é que se legitima um direito fundamental como garantia individual, pois nem sempre a esmagadora maioria tem razão e não raras vezes o direito encerra uma grande injustiça ${ }^{27}$.

Fincadas essas premissas, o trabalho centrará esforços de reflexão somente em duas garantias que escorrem daquele Tribunal Popular e que bastam para justificar absolvição por clemência deliberada no Conselho de Sentença, quais sejam, sigilo das votações e soberania dos veredictos. Esses mesmos princípios legitimam o funcionamento do Júri em modo diverso da lógica técnica preconizada pelo formalismo do direito oficial, porquanto ambos estão previstos na Constituição Federal justamente para afastar o controle estatal sobre o mérito das decisões tomadas em colegiado por Juízes Leigos, porque em respeito àquelas garantias não se precisa fundamentar as decisões tomadas sempre em caráter privado ${ }^{28}$, e muito menos submetê-las ao duplo grau de jurisdição quanto ao mérito do veredicto ${ }^{29}$.

Sigilo das votações implica proteger a íntima convicção dos Jurados Leigos a respeito do caso e também a desnecessidade de motivar sua decisão, tanto que o escrutínio do julgamento restará encaminhado pela Presidência do Tribunal na forma sumária de questionário e respondido em sala secreta ${ }^{30}$. Esse rigoroso procedimento assegura o final protagonismo dos jurados quando, guiados somente por compreensões emanadas dos seus respectivos juízos morais e éticos, expressam o livre convencimento a respeito do mérito da causa, respondendo apenas "sim" ou "não" num ambiente reservado e seguro, assim como afastado da pressão popular e possibilitando uma não necessária motivação (OLIVEIRA, 2009).

Decorre desse juízo aparentemente descontrolado e popular (pelo menos na sua maneira representativa) justamente outra garantia constitucional por ora eleita, qual seja, a soberania dos veredictos daquele Tribunal de Leigos. E quando se proclama soberana aquela decisão proferida pelo Conselho de Sentença, após discussão plenária no Júri, deve-se entendê-la como expressão técnico-jurídica que deve ser definida segundo a ciência dogmática do processo penal, e não de acordo com uma exegese de lastro filológico, alimentada em esclarecimentos vagos de dicionários (MARQUES, 1997).

\footnotetext{
${ }^{26}$ Cláusulas Pétreas são aquelas matérias constantes do Texto Constitucional e imunes ao poder de reforma por proposta de emenda, tendo seu núcleo intangível e não podendo ser abolido, nos termos do art. 60 , parágrafo $4^{\circ}$, da $\mathrm{CF} / 88$.

27 A respeito dessa temática, sugere-se a leitura do seguinte texto: "A função contramajoritária dos direitos fundamentais", publicada na Revista Eletrônica Conjur de 27 de abril de 2015, por Luciana Vieira Dallaqua Vinci e Wilson José Vinci Júnior, disponível no sítio eletrônico https://www.conjur.com.br/2015-abr-27/mp-debate-funcao-contramajoritaria-direitos-fundamentais.

${ }^{28}$ Nos juízos técnicos e como obrigação inafastável por parte dos Magistrados Togados, sob pena inclusive de nulidade, todos os julgamentos serão públicos e suas decisões fundamentadas, à luz do que dispõem o art. 93, inciso IX, da Constituição Federal.

${ }_{29}$ Notadamente à soberania das decisões do Júri e seu posterior controle por um Colegiado formado por juízes técnicos, somente em uma hipótese se tem admitido, qual seja, naquela previsão estampada no art. 593, inciso III, alínea "d", do CPP, e autorizada nos casos de decisão manifestametne contrári à prova dos autos, como restará mais adiante explorado.

${ }^{30}$ Acerca dessa formalidade e todas as fases do julgamento, precipuamente aquele rito que vai desde a formulação do questionário até sua final votação, recomenda-se consultar os arts. 482 usque 491, do Código de Processo Penal.
} 
E o Código Adjetivo Penal, alimentado por interpretações dadas pelo STJ em casos específicos de clemência (como se verá mais adiante), procura melhor regulamentar aquela Instituição e também temperar o absolutismo dessa soberania popular, ao impor apenas uma única restrição ao veredicto, sem adentrar no mérito do juízo de valor e meramente inclinado para o exame formal. Essa previsão consta do art. 593, inciso III, alínea "d", parágrafo $3^{\circ}$, do CPP, quando autorizou recurso contra a decisão dos Jurados na hipótese de decisão manifestamente contrária à prova dos autos, cabendo provimento revisional somente para sujeitar o réu a novo julgamento, não se admitindo uma segunda apelação para o caso e pelo mesmo motivo.

Esse ponto limitador, sem dúvida alguma, se tornou na hipótese mais controversa e complexa de todas as questões a envolver o procedimento do Tribunal Popular no Júri, uma vez que mal operado na prática pode ferir de morte o primado constitucional da soberania dos veredictos. Certo é que nesse específico caso o direito ao duplo grau de jurisdição deve ser manejado com muita parcimônia e respeito com aquela garantia constitucional, não sendo possível - sob qualquer pretexto - Cortes Togadas invadirem o mérito do veredicto para substituí-lo, pois se houver erro judiciário devidamente reconhecido, basta remeter o caso para novo julgamento daquele Tribunal Popular, mas jamais invalidar o pronunciamento dos representantes do povo a fim de proferir outra decisão, ainda que técnica e respeitante ao pano de fundo da mesma discussão (NUCCI, 1999).

Não bastasse toda essa controvérsia, ela ainda se torna mais acentuada quando verifica-seno caso concreto possível decisão tomada pelo Júri e que se revela manifestamente contrária à prova existente nos autos, no estrito exercício da sua peculiar soberania e não raras vezes vencedoras teses que escapam do argumento técnico, se aproximando muito mais do campo metafísico da clemência, como se prosseguirá argumentado.

\section{ABSOLVIÇÃO GENÉRICA POR CLEMÊNCIA E O POSICIONAMENTO DO STJ}

Em razão das alterações sofridas pelo atual Código de Processo Penal na maneira de se formular os quesitos que serão apresentados aos Membros Leigos do Conselho de Sentença para fins de encaminhamento do final veredicto ${ }^{31}$, abriu-se uma fenda de oportunidades para que surjam decisões manifestamente contrárias às provas dos autos e, bem por isso, passíveis de conhecimento e posterior julgamento em grau de recurso pela Instância Técnica de Segundo Grau.

A questão que se coloca como de possível conflito e anteriormente aventada diz respeito à possibilidade legal de que, mesmo reconhecendo os Jurados que o fato delituoso ocorreu e o réu sob

\footnotetext{
${ }^{31}$ Ditas alterações restaram promovidas pela Lei Federal n. 11.689/2008, reconhecidamente promovedora de algumas reformas pontuais do atual Código de Processo Penal.
} 
acusação cometeu o crime imputado, delibere o Colegiado Popular por genericamente absolvê-lo em vista de alguma causa não prevista exclusivamente como excludente de punibilidade no Código Repressivo Oficial Brasileiro, como - e a exemplo do que se debate neste arrazoado - perdoá-lo por clemência.

Melhor esclarecendo, agora os quesitos serão apresentados aos Jurados e que deverão necessariamente ser por eles respondidos como "sim" ou "não", na forma sigilosa e sem necessidade de fundamentação, guardam a seguinte sequência lógica, assim previstos no CPP, litteris:

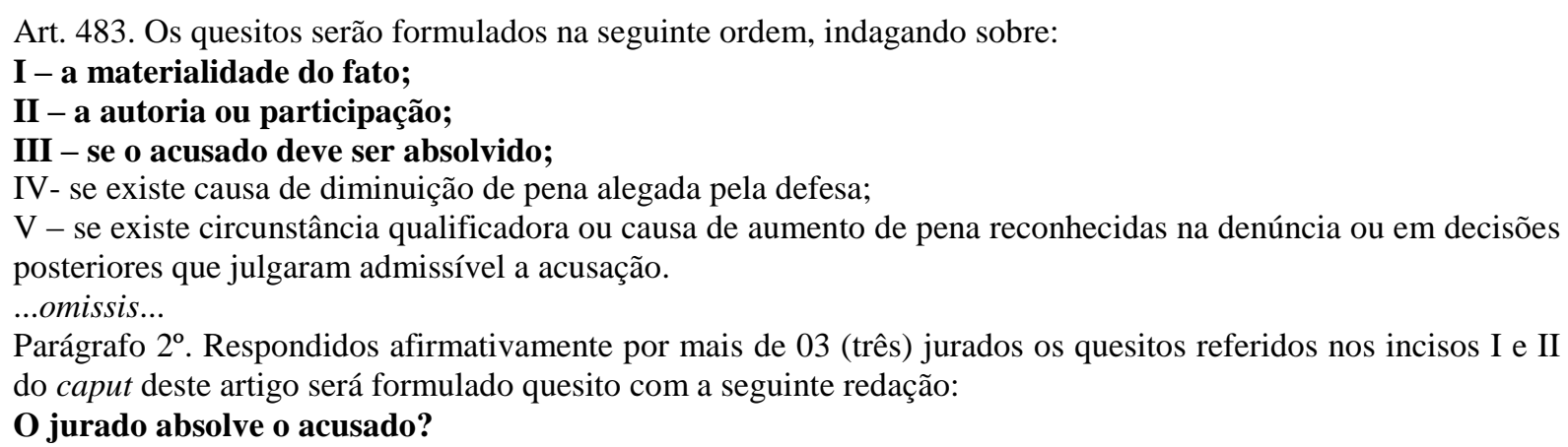
...omissis... (Grifo nosso).

Por ser proposta deste trabalho, o exame limita-se aos incisos I, II e III, aplicando-se também o decorrente parágrafo segundo, se acaso for afirmativa a resposta para os dois primeiros. Com efeito, resta possibilitada então a hipótese de uma absolvição genérica por parte do Conselho de Sentença que, mesmo reconhecendo haver materialidade do delito e sua autoria tecnicamente provada no curso do processo, podem absolver o réu sem qualquer justificativa e desconforme com os elementos carreados para os autos, comovidos exclusivamente por sentimentos de bondade e vertendo para uma decisão clemente em relação ao acusado.

Obviamente que diante desse resultado aparentemente incoerente com a realidade materializada dentro do processo, o Órgão de Acusação pode perfeitamente manejar apelação para reformar o veredicto, com fulcro na única hipótese legal que possibilita a impugnação daquela soberana decisão popular, qual seja, revisão do julgamento porque a decisão dos jurados foi manifestamente "contrária à prova dos autos", somente pugnando-se pelo provimento do recurso para que novo julgamento pelo Tribunal Popular e a respeito do mesmo caso novamente se realize, devolvendo o feito para o Juízo de Primeiro Grau a fim de que outra seção plenária aconteça, ex vi do art. 593, inciso III, alínea “d”, parágrafo 3, CPP.

Diante dessa recente alteração processual, com a criação daquela hipótese genérica de absolvição e a partir do realinhamento de quesitos mais simplificados para serem ofertados aos Jurados, transparece a seguinte e aparente contradição: - como fica a soberania dos veredictos do Júri se acaso os representantes do povo escolhidos para comporem o Conselho de Sentença deliberem por absolver alguém, imbuídos 
unicamente pelo sentimento de clemência, contrariando provas constantes dos autos e ainda que tenham anteriormente votado pela materialidade do fato e autoria do crime?

Esse tem sido um dos grandes tormentos jurídicos no bojo do Tribunal Popular, pendente ainda de pacificação tanto nos foros doutrinários quanto dentro do próprio Superior Tribunal de Justiça (STJ), onde há diversos precedentes sobre o tema, alguns favoráveis e outros contrários a permissão de o Júri deixar de condenar o réu por clemência, suscitando as mais variadas teses e diferentes maneiras de interpretar o direito posto (GRILLO, 2016).

Entrementes, e nitidamente a partir do julgamento do Habeas Corpus n. 350.895-RJ pela Sexta Turma do STJ, concluído em 14 de março de 2017, a discussão começou a tomar contornos mais nítidos e talvez brevemente se encaminhando para um norte conciliatório ${ }^{32}$. Naquela ocasião se debateu abertamente a possibilidade da absolvição por clemência, enquanto fundamento metafísico não previsto na legislação penal como excludente de culpabilidade e os seus desdobramentos acerca da eficácia do princípio da soberania dos veredictos populares.

Sem maiores aprofundamentos no caso, resumidamente compete por ora registrar que a Relatora originária daquele Habeas Corpus, Ministra Maria Thereza de Assis Moura, verificou a ausência do enfrentamento específico por parte do Tribunal de Apelação quanto à possibilidade dos jurados entenderem pela clemência ou perdão do réu e, justamente por isso, naquela superior fase recursal se mostrava inviável a cognição da tese defensiva, sob pena da indevida supressão de instância por parte do STJ. No entanto, constatou naqueles autos a existência de constrangimento ilegal, a restar sanado de ofício, porque entendeu possível analisar a alegação da clemência defendida nas contrarrazões recursais e também sustentada na respectiva seção de julgamento.

Após pedido de vista, o Ministro Sebastião Reis Júnior trouxe voto escrito onde apontava discrepâncias sobre a matéria dentro do próprio STJ, mas assentando posicionamento reiterado quando se proclamou a possibilidade de o Tribunal Popular absolver o acusado, ainda que tenha respondido afirmativamente aos quesitos referentes à autoria e à materialidade, por respeito à sua soberania e sem que a defesa tivesse suscitado tese absolutória da negativa de existência do fato ou da autoria.

Para ele, o entendimento de que o Tribunal do Povo não poderia absolver o réu, caso reconhecesse a materialidade e autoria, também seria diretamente contrário às determinações do art. 483 do CPP, uma vez que nos termos dos parágrafos $1^{\circ}$ e $2^{\circ}$, a votação do quesito absolutório genérico somente ocorre quando há resposta afirmativa em relação aos quesitos referentes à materialidade e à autoria. Nesse sentido, lembrou que o STJ tem posicionamento firme no sentido de que o quesito absolutório é genérico porque deve ser

\footnotetext{
${ }^{32}$ Para ter acesso ao inteiro teor desse julgado, com todos os votos escritos proferidos, sugere-se acessar o sítio eletrônico do próprio Superior Tribunal de Justiça, a saber: http://www.stj.jus.br.
} 
formulado independentemente das teses apresentadas em Plenário, por observância ao princípio da plenitude da defesa e ainda soberania dos veredictos.

Vencida essa etapa de argumentação, passou a enfrentar questão referente aos limites do Tribunal de Apelação quando da análise de recurso acusatório interposto com fundamento no art. 593, inciso III, alínea “d”, c/c. o seu parágrafo $3^{\circ}, \mathrm{CPP}$; ou seja, sob a alegação de que o veredicto foi manifestamente contrário à prova dos autos. É nesse toar que vem a contribuição do STJ, temperando fundamentos de soberania com os limites estabelecidos por aquela lei processual, assim como por homenagem ao direto do duplo grau de jurisdição.

Depois de examinar com acuidade anteriores acórdãos firmados pelo STJ para casos análogos, apontou o Ministro Sebastião Reis Júnior existir precedentes que, inobstante absolver o acusado mesmo quando reconhecida materialidade e autoria do delito, firmavam tese de que não retiraria da Corte Recursal a oportunidade de aferir, por uma única vez, se o julgamento teria sido manifestamente contrário à prova dos autos.

No sentir daquele Magistrado, seria mais adequada ao sistema previsto no Código de Processo Penal que a validade da anulação proferida pelo Tribunal de Apelação, sob o pretexto anteriormente ventilado, dependesse exclusivamente dos argumentos utilizados para respaldar a conclusão no sentido de se verificar, in concreto, se realmente o julgamento se deu manifestamente contrário à prova dos autos. Essa detalhada análise fática realizada sobre o acervo probatório colhido ao longo da instrução criminal é que legitimaria concluir se, no desencadear dos acontecimentos, encontra-se ou não presente um lastro mínimo de concretude a justificar aquela absolvição operada pelo Júri, afastando-se eventual juízo geral e abstrato da mera presunção.

Forte nesse encaminhamento, concluiu ser possível ao Tribunal Revisional, por uma única vez, anular o julgamento proferido pelo Júri que absolve o acusado, apesar de reconhecer autoria e materialidade, sob o fundamento de ser contrário à prova dos autos, desde que o faça a partir de uma fundamentação idônea, lastreada em elementos probatórios concretos colhidos ao longo da instrução e não apenas em mera presunção.

Desde que alinhado com essa toada de precaução, compreende também como legítimo o veredicto do Júri que absolveu o réu por clemência, não vinculado a qualquer tese defensiva específica, mas sempre respaldado nos elementos fáticos constantes dos autos, ainda que mínimos de substrato, mas com força razoável e suficiente para autorizarem sua concessão.

Ao final do voto vista, explicou que no tocante à clemência, deve ser ressaltado que o elemento fático que pode dar suporte à sua concessão não é, necessariamente, inerente ou mesmo contemporâneo ao crime sob julgamento, como por exemplo, quando o acusado, após prática do delito, veio a ser cometido de doença grave e, por essa razão, restou pedida sua clemência ao Júri, que acaba por absolvê-lo. 
Naquele julgamento, findou sua manifestação evidenciando que, no caso concreto, o Tribunal de origem, ao anular o julgamento do Júri, não evidenciou que a absolvição estaria divorciada das provas colhidas na instrução processual e, tampouco, demonstrou que o pedido de clemência e sua acolhida estariam desamparados de suporte fático mínimo, concluindo apenas que o julgamento seria contrário à prova dos autos a partir de mera presunção, razão pela qual votou pela concessão da ordem para o fim de cassar o acórdão da apelação e restabelecer a absolvição proferida pelo Tribunal Popular. Acompanhado pela maioria, seu voto condutor se prestou para sustentar a decisão concessiva, bem como foi destacado para lavrar o mesmo acórdão.

Mais recentemente, e na linha ponderada pelo Habeas Corpus n. 350.895-RJ, veio ementado dentro do mesmo STJ o Recurso Especial n. 1.345.329-DF, relatado pelo Ministro Reynaldo Soares da Fonseca e julgado em 15 de março de $2018^{33}$, reiterando entendimento que naquela Corte não se visa criar óbice ao reconhecimento da possibilidade conferida aos jurados de absolver o acusado por sentimentos altruísticos, até mesmo por clemência; ao contrário, o que se ressalva é o fato de ser tal absolvição desassociada de qualquer elemento mínimo de prova e, desse modo, ilegal, injusta, arbitrária, e até mesmo inconstitucional, premissas inadmissíveis em um Estado que se diz democrático de direito.

Também naquele julgamento se repetiu tese de que a absolvição do acusado pelos Jurados com base no art. 483, inciso III, CPP, não constitui decisão irrecorrível, podendo o Tribunal de origem, em sede de apelação, cassá-la, quando verificar que a conclusão alcançada pelo Conselho de Sentença é absolutamente dissociada das provas apresentada no transcorrer do processo e sede plenária. Tal hipótese (art. 593, inciso III, “d”, CPP), apesar de excepcional, não ofende a soberania dos veredictos (art. 50, inciso XXXVIII, "c", $\mathrm{CF}$ ), uma vez que exige a submissão do caso a novo Júri, caracterizando um mínimo de controle do duplo grau de jurisdição e no intuito de evitar não apenas excessos, como também arbitrariedades desmedidas.

Entenderam ainda naquele julgamento os Senhores Ministro do STJ que somente será inatacável a opção dos Jurados que não seja manifestamente e minimamente contrária à prova dos autos. A mesma conclusão é alcançada na hipótese de absolvição por clemência. Muito embora possível tal resultado em julgamento pela Corte Popular, a decisão será passível de revisão pelo Tribunal ad quem quando não houver respaldo fático mínimo nos autos que dêem suporte à benesse. Com esses temperamentos, ponderando soberania do Júri com limites processuais garantidores ao duplo grau de jurisdição, vem se comportando o STJ, tendo justamente a hipótese da clemência como o seu fundamento de análise.

\section{CONCLUSÃO}

\footnotetext{
${ }^{33}$ Também quanto a este julgado, sugere-se acesso pelo link http://www.stj.jus.br, onde estarão disponíveis ementa, acórdão e voto condutor.
} 
Após exame dos argumentos conciliatórios cingidos ao âmbito do STJ, se percebe um grande esforço jurisprudencial no sentido de equilibrar qualidade soberana do Júri com um mínimo de controle estatal que seja sobre a vontade popular ali representada, em prestígio ao regular funcionamento do que se convencionou chamar de Estado Democrático de Direito, cujo sistema opera com o propósito de corrigir eventuais arbítrios indesejáveis e ainda para garantir o duplo grau de jurisdição como um direito da sociedade, representada em plenário pelo Ministério Público e que na ocasião fez às vezes de Órgão da Acusação.

Nesse compasso, e ao fundamento de emprestar uma interpretação conforme ao mecanismo de apelo que possibilita revisão daquele julgamento quando manifestadamente contrário às provas dos autos, encontrou-se dentro do STJ um modo de compor essa regulação processual com o devido respeito que se deve ter à decisão do Tribunal Popular, vertendo para uma interferência mínima e desde que fundada em elementos que autorizassem um novo julgamento, a ser realizado pelo plenário de origem e com a devolução dos autos para a Primeira Instância.

Desse modo, não se imiscui no mérito do veredicto soberano, mas por apresentar uma desconformidade probatória razoável e mínima com a realidade do quadro processual, a Corte de Apelação deixa de reexaminar provas para, diante dessa irregularidade que entende-se formal, se encaminha os autos para novo julgamento do caso, ponderando no limiar da não interferência estatal o duplo grau de jurisdição como garantia social.

E nada mais satisfatório do que enfrentar essa aparente contradição a partir da complexa discussão sobre o que secularmente se convencionou denominar de clemência, virtude dos Deuses que foi paulatinamente arvorada pelos homens, até chegar ao dias de hoje como expressão intimamente ligada aos direitos e garantias fundamentais. O denso conteúdo dessa categoria pensada originariamente no campo da filosofia se revelou em tempos presentes como forte questão e apta a desafiar os rigores metodológicos do direito, porquanto norteadora não apenas dos sentimentos de bondade, mas sobretudo ligada à possibilidade altruísta do perdão.

Como ficou demonstrado no curso deste texto, num autêntico Estado Democrático de Direito quem exerce agora soberania não é mais o Imperador, senão os lídimos representantes do povo. Somente eles têm o direito e legitimidade formal para julgar com clemência. E o Conselho de Sentença por eles encarnado é quem legalmente está autorizado a praticar virtude do perdão.

É por isso que no juízo técnico exercido pelo STJ - nem mesmo por qualquer outro Magistrado investido pelo Estado - competiria examinar o mérito ou proclamar clemência, uma vez que arrostam o compromisso de sempre fundamentar tais decisões segundo princípios e regras estabelecidas pelo direito, onde não se previu aquela possibilidade de perdão como excludente da punibilidade. 
Diante de tais considerações parece acertado aquele arranjo processual e por ora resumidamente descrito nesta conclusão, mais compatível com os comandos constitucionais aplicáveis à espécie e sem descurar da estreita observância aos rigores formais, que também se denotam como garantias individuais observadas e ofertadas dentro das estruturas do Estado.

\section{REFERÊNCIAS}

ARAÚJO, Nádia; ALMEIDA, Ricardo. R. O tribunal do júri nos Estados Unidos - sua evolução histórica e algumas reflexões sobre seu estado atual. Revista Brasileira de Ciências Criminais, n. 15, São Paulo, 1996.

COOK, John A. Consilium Principis. Cambridge: University Press, 1955.

DUROZOI, Gérard; ROUSSEL, André. Dicionário de filosofia. 2. ed. Tradução de Marina Appenzeller. Campinas: Papirus, 1996.

FERREIRA, Aurélio B. Holanda. Dicionário Aurélio da língua portuguesa. 5. ed. Curitiba: Positivo, 2014.

GRILLO, Brenno. Conflito de precedentes: STJ analisa se tribunal do júri é soberano para absolver réu por clemência. Consultor Jurídico. São Paulo, 16/abr./2016. Disponível: http//www.conjur.com.br.

MARQUES, José Frederico. A instituição do Júri. Campinas: Bookseller, 1997.

NUCCI, Guilherme de Souza. Júri: princípios constitucionais. São Paulo: Juarez de Oliveira, 1999.

OLIVEIRA, Eugenio Pacelli de. Curso de processo penal. Rio de Janeiro: Lúmen Júris, 2009.

OLIVEIRA, Luizir de. Sêneca, a vida na obra. Dissertação (Mestrado). Departamento de Filosofia. Pontifícia Universidade Católica de São Paulo. São Paulo: 1998.

SÊNECA. Tratado sobre a clemência. Tradução de Ingeborg Braren. Petrópolis: Vozes, 1990.

SILVA, De Plácido e. Vocabulário jurídico. Vol. I. 4. E.d.Rio de Janeiro: Forense, 1975.

TUCCI, Rogério Lauria. Tribunal do Júri: estudo sobre a mais democrática instituição jurídica brasileira. São Paulo: RT, 1999.

VINCI, Luciana Vieira Dallaqua; VINCI JÚNIOR, José. A função contramajoritária dos direitos fundamentais. Revista Eletrônica Conjur. 27 de abril de 2015. Disponível: https://www.conjur.com.br/2015-abr-27/mp-debate-funcao-contramajoritaria-direitos-fundamentais, acessado em 11/nov./2018. 